\title{
Optical bone density as a prognostic risk factor for the development of medication-related osteonecrosis of the jaw in patients with bone metastases
}

\author{
N.G. Vinogradova ${ }^{1,2}$, L.V. Solomatina ${ }^{3}$, M.P. Kharitonova ${ }^{1}$, K.V. L'vov' ${ }^{2}$ D.Yu. Borzunov ${ }^{1,2}$ \\ ${ }^{1}$ Ural State Medical University, Ekaterinburg, Russian Federation \\ ${ }^{2}$ Central City Clinical Hospital, Ekaterinburg, Russian Federation \\ ${ }^{3}$ Institute of Immunology and Physiology of the Ural Branch of the Russian Academy of Sciences, Ekaterinburg, Russian Federation
}

\begin{abstract}
Introduction Medication-related osteonecrosis of the jaw (MRONJ) is a complication associated with the intake of osteomodifying agents (bisphosphonates, denosumab). At present, its frequency, according to various authors, may reach from one to 10 cases per 100 subjects. The literature describes the main factors in the pathogenesis of the disease. The prognostic signs of its development, which would allow timely diagnosis and prevention of the disease, remain not fully understood. Materials and methods The retrospective analysis was based on the results of a study of 52 patients with MRONJ who were treated at the Department for Maxillofacial Surgery at the Central City Hospital No. 23 in Yekaterinburg from January 2015 to December 2019 Multispiral computed tomography was used for visualization, quantitative and qualitative assessment of the jaw bone tissue. The optical density of the spongy substance was determined in Hounsfield units (HU) on the side opposite to the lesion. Results The analysis of the results of optical density showed that D1 bone type was not detected in any patient. We observed type D2 using CT in 5 cases in the central part of the lower jaw (9.61\%), in 9 cases in the central part of the upper jaw $(17.3 \%)$, as well as in the area of the angle of the lower jaw on 6 CT-scans $(11.53 \%)$. D3 and D4 bone types prevailed, D5 bone type was less common. The optical density of the structures under study was in the range from $229.8 \pm 56.6$ to $534.8 \pm 155.4 \mathrm{HU}$. Thus, patients receiving osteomodifying therapy with bone types D3, D4, D5 are more at risk of developing MRONJ than patients with bone types D1 and D2. Conclusion It is advisable to include a mandatory MSCT with classification of bone types according to Misch and determine optical density of bone tissue in the examination protocols of such patients.
\end{abstract}

Keywords: osteonecrosis of the jaw, osteomodifying agents, optical density

\section{INTRODUCTION}

Medication-related osteonecrosis of the jaw (MRONJ) is a complication associated with the intake of osteomodifying agents (OMA), bisphosphonates, denosumab $[1,2]$. The main mechanism of action of these drugs is to inhibit the functioning of osteoclasts, thereby blocking pathological bone remodeling and reducing the risk of bone metastases in malignant neoplasms, osteoblastoclastoma, and myeloma [3-6]. Currently, the frequency of MRONJ, according to various authors, can reach from 1 to 10 cases per 100 subjects $[4,6]$. There are some physiological features in the structure of the jaw bones that suggest the cause and localization of MRONJ in this particular part of the skeleton. Of all the bones, the jaw is the most unprotected from the point of view of bacterial infection, since the mucous membrane covering the bone is very thin and sensitive. It is known that the triggering factor in the development of osteonecrosis is the extraction of a tooth or a pressure ulcer on the mucous membrane of the alveolar process of the jaw due to excessive pressure of the prosthesis on the prosthetic bed [7-9].
This pathology has a specific clinical and radiographic symptomatic complex: primary chronic course, pronounced pain before the appearance of the first objective manifestations of the jaw lesion, absence of classical signs of bone sequestration when radiation methods of examination are used. The literature describes the main factors of the pathogenesis of the disease such as impaired remodeling, antiangiogenic effects of drugs, local toxic effect on soft tissues, as well as general nonspecific factors (intake of cytostatics, concomitant pathology, and others) $[10,11]$.

Despite the long-term study of the pathogenesis of MRONJ, the prognostic signs of its development remain not fully understood which would allow for timely diagnosis and prevention of its occurrence.

The aim of the study was to identify predictive criteria for the risk of developing MRONJ, based on an objective assessment of bone quality by determining its optical density with multislice computed tomography.

\section{MATERIAL AND METHODS}

Our retrospective analysis was based on the results of 52 patients with MRONJ who were treated at the Department for Oral and Maxillofacial Surgery of the Central City Hospital No. 23 in Yekaterinburg from
January 2015 to December 2019. The study included patients with malignant neoplasms (MN) of different localization and established bone metastases (Table 1). Among them, 28 were men (53.85\%) and 24 were women

Dd Vinogradova N.G., Solomatina L.V., Kharitonova M.P., L’vov K.V., Borzunov D.Yu. Optical bone density as a prognostic risk factor for the development of medication-related osteonecrosis of the jaw in patients with bone metastases. Genij Ortopedii, 2020, vol. 26, no 4, pp. 539-543. DOI 10.18019/1028-4427-2020-26-4-539-543 
$(46.15 \%)$. The average age was $66.8 \pm 10.03$ years. The mean treatment period for OMA was $3.4 \pm 1.9$ years.

Table 1

Distribution of patients according to the location of the primary focus with established metastases in the bones

\begin{tabular}{|l|c|c|}
\hline \multirow{2}{*}{$\begin{array}{c}\text { Location of the primary focus and } \\
\text { established metastases in bones }\end{array}$} & \multicolumn{2}{|c|}{ Patients } \\
\cline { 2 - 3 } & Number & $\%$ \\
\hline MN prostate & 19 & 36.53 \\
\hline MN mammal gland & 12 & 23.08 \\
\hline MN lungs & 10 & 19.23 \\
\hline MN uterus & 4 & 7.69 \\
\hline MN kidney & 2 & 3.85 \\
\hline MN intestine & 1 & 1.92 \\
\hline Lymphoma & 2 & 3.85 \\
\hline Myeloma & 2 & 3.85 \\
\hline Total & 52 & 100 \\
\hline
\end{tabular}

All patients received chemotherapy with OMA drugs according to clinical guidelines in specialized hospitals [12].

The clinical picture in all patients is similar. They complained of intensive pain radiating along the branches of the trigeminal nerve and the intensity of pain on a VAS scale was 5.5-7 points. By objective examination, the face was symmetrical, or there was a slight edema on the affected side. The skin had physiological color. The mouth opened fully or slightly limited. Examination of the oral cavity revealed fistulous passages with purulent discharge or a defect in the mucous membrane of various diameters on the alveolar process of the jaw. The bone in the defect was of grey color with a putrid smell (Fig. 1).

The diagnosis of medication-related osteonecrosis was established according to the following criteria:

- presence of an exposed bone in the mouth for 8 weeks or more;

- current OMA treatment or in the past;

- no history of radiation therapy [13].

To determine the stage of osteonecrosis, we used the classification proposed by Russian researchers [14]. According to this classification, depending on the prevalence of the process, there are three stages of the disease:

- Stage 1 with an area of exposed bone tissue within 1tooth hole.

- Stage 2 with an area of exposed bone tissue within 2 or more holes within one quadrant (quadrant is a segment of the tooth row from the central incisor to the last molar) or 1-2 teeth within two quadrants.

- Stage 3 with an area of exposed bone tissue, including three or four quadrants, or presence of a pathological fracture of the jaw or involvement in the process of the mandibular canal, mandibular branch, the maxillary sinus or the floor of the nasal cavity.

We observed stage 1 osteonecrosis in $23.1 \%$ of cases $(n=12)$, the disease was detected in stage 2 in $57.7 \%(\mathrm{n}=30)$, stage 3 osteonecrosis was detected in $19.2 \%(\mathrm{n}=10)$.

Multispiral computed tomography (MSCT) was used for visualization, quantitative and qualitative assessment of the jaw bone tissue. The study was performed on a Toshiba Aquilion RXL multispiral computed tomography system (Toshiba Medical Systems Corporation, Odawara, Japan) at the Department of Radiation Diagnosis of the Central City Clinical Hospital No. 23 in Yekaterinburg. The nominal power of X-ray radiation at the output is $60 \mathrm{~kW}$, the slice thickness is $1.0 \mathrm{~mm}$, and the scanning speed is $0.5 \mathrm{~s}$ per revolution. The optical density of the cancellous substance was determined in Hounsfield units (HU) on the side opposite to the lesion: the mental region, angle, branch on the lower jaw; the central region and the region of the tubercle on the upper jaw. The Misch classification was used to determine the type of bone [15].

The data were statistically processed using the IBM SPSS Statistics 26 software package. The mean $(\mathrm{M})$, median $(\mathrm{Me})$, and standard deviation $(\sigma)$ were determined. To check the distribution normality, the Kolmogorov-Smirnov normality test was used; the nonparametric Kruskal-Wallis test was used to compare the groups. The results were considered statistically significant at $\mathrm{p}<0.05$.
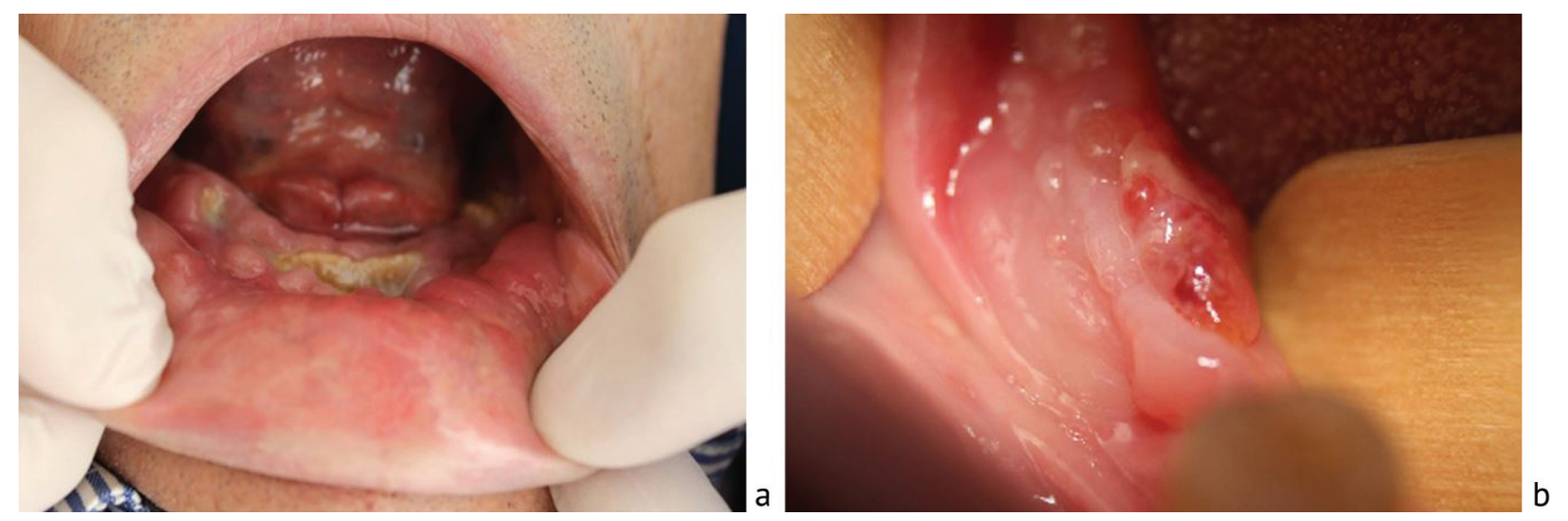

Fig. 1 Photo of the oral cavity: $\boldsymbol{a}$ areas of exposed bone in the oral cavity; $\boldsymbol{b}$ sinuses on the mucous membrane of the alveolar process of the lower jaw 


\section{RESULTS}

In CT scans, we visualized the absence of a clear demarcation line at the border of a healthy bone and the one involved in the process at stages 1 and 2, periosteal reaction at stage 3 of the disease (Fig. 2), which corresponds to the data presented in Russian and foreign literature [16-18].

The results of optical density determination were as follows. Bone type D1 (>1250 HU) was not detected in any patient. We observed type D2 in the analysis of CT in five cases in the central part of the lower jaw, in nine cases in the central part of the upper jaw, as well as in six CT-scans in the area of the lower jaw angle. Bone types D3 and D4 dominated, bone type D5 was less common (Table 2).

Values of optical density depended on the bone type according to Misch classification (Table 3).

We also found that there are intragroup differences in density depending on the area studied. Thus, in D3 bone type the average value was $571.25 \pm 9064 \mathrm{HU}$ in the central part of the lower jaw, and in the area of the lower jaw angle it was $509.94 \pm 118.6 \mathrm{HU}$ (Table 4).
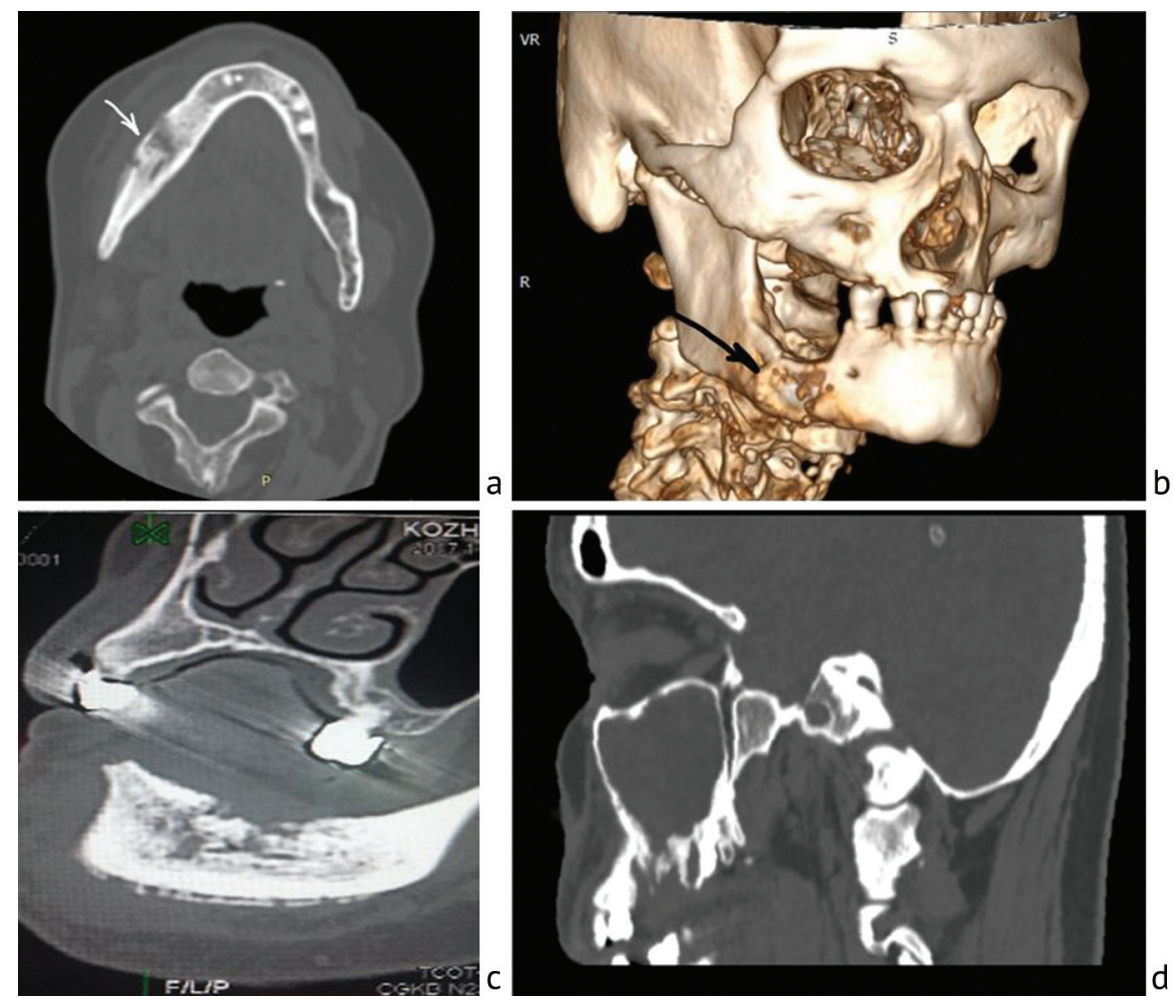

Fig. $2 \boldsymbol{a}$ axial MSCT section (bone window) of the lower jaw with MRONJ; b $3 \mathrm{D}$ reconstruction in MRONJ; $c$ sagittal MSCT section of the lower jaw with MRONJ; $\boldsymbol{d}$ sagittal MSCT section (bone window) with MRONJ of the upper jaw

Table 2

Results of optical density measurement

\begin{tabular}{|c|c|c|c|c|c|c|c|c|c|c|}
\hline \multirow{4}{*}{ Bone type } & \multicolumn{10}{|c|}{ Number of patients } \\
\hline & \multicolumn{6}{|c|}{ Lower jaw } & \multicolumn{4}{|c|}{ Upper jaw } \\
\hline & \multicolumn{2}{|c|}{ Central part } & \multicolumn{2}{|c|}{ angle } & \multicolumn{2}{|c|}{ branch } & \multicolumn{2}{|c|}{ Central part } & \multicolumn{2}{|c|}{ Tubercle } \\
\hline & abs & $\%$ & abs & $\%$ & abs & $\%$ & abs & $\%$ & abs & $\%$ \\
\hline $\mathrm{D} 2(850-1250 \mathrm{HU})$ & 5 & 9.6 & 6 & 11.5 & & & 9 & 17.3 & & \\
\hline D3 (350-850 HU) & 26 & 50.0 & 15 & 28.8 & 22 & 42.3 & 15 & 28.8 & 15 & 28.8 \\
\hline $\mathrm{D} 4(150-350 \mathrm{HU})$ & 10 & 19.2 & 16 & 30.8 & 16 & 30.8 & 14 & 26.9 & 25 & 48.1 \\
\hline D5 $(<150 \mathrm{HU})$ & 11 & 21.2 & 15 & 28.8 & 14 & 26.9 & 14 & 26.9 & 12 & 23.1 \\
\hline Total & 52 & 100 & 52 & 100 & 52 & 100 & 52 & 100 & 52 & 100 \\
\hline
\end{tabular}

Table 3

Mean values of optical density in Misch bone types

\begin{tabular}{|l|c|c|}
\hline \multirow{2}{*}{ Bone type } & \multicolumn{2}{|c|}{ Mean density (HU) } \\
\cline { 2 - 3 } & Me & M $\pm \sigma$ \\
\hline D2 $(850-1250 \mathrm{HU})$ & 866.35 & $894.98 \pm 83.23$ \\
\hline D3 $(350-850 \mathrm{HU})$ & 559.03 & $534.77 \pm 155.38$ \\
\hline D4 $(150-350 \mathrm{HU})$ & 218.07 & $229.80 \pm 56.62$ \\
\hline D5 $(<150 \mathrm{HU})$ & 101.4 & $96.18 \pm 38.6$ \\
\hline
\end{tabular}

Notes: $\mathrm{Me}-$ median, $\mathrm{M}$ - mean value, $\sigma$ - standard deviation. Significant difference between the groups according to Kruskal-Wallis test $(\mathrm{p}<0.05)$ 
Mean values of optical density in the areas studied

\begin{tabular}{|l|c|c|c|c|c|}
\hline \multirow{3}{*}{ Bone type } & \multicolumn{5}{|c|}{ Lone density (HU), M $\sigma$} \\
\cline { 2 - 6 } & \multicolumn{3}{|c|}{ Lower jaw } & \multicolumn{2}{c|}{ Upper jaw } \\
\cline { 2 - 6 } & Central part & angle & Branch & Central part & \\
\hline D2 & $1001.9 \pm 87.75$ & $903.09 \pm 69.56$ & & $848.97 \pm 20.08$ & $427.124 \pm 124.06$ \\
\hline D3 & $571.25 \pm 90.64$ & $509.94 \pm 118.6$ & $579.48 \pm 168.71$ & $536.57 \pm 214.93$ & $206.28 \pm 46.01$ \\
\hline D4 & $243.59 \pm 67.39$ & $201.18 \pm 58.05$ & $232.54 \pm 60.28$ & $268.99 \pm 48.21$ & $70.9 \pm 34.19$ \\
\hline D5 & $112.98 \pm 62.32$ & $102.16 \pm 40.68$ & $81.63 \pm 35.96$ & $142.21 \pm 5.18$ & \\
\hline
\end{tabular}

Note: $\mathrm{M}-$ mean value; $\sigma-$ standard deviation

\section{DISCUSSION}

A lot of works have been devoted to the study of the MRONJ problem. The literature describes in detail the radiological signs characteristic of this particular disease, including the stages of the disease $[8,19,20]$. However, there are few studies dedicated to prognostic criteria based on objective indicators. We assume that the quality of the bone, architectonics of the bone tissue play a role in the development and outcome of the disease. It is known that the D1 bone type according to Misch is a compact and dense bone tissue corresponding to the cortical layer. In bone type $\mathrm{D} 2$, there is a certain polymorphism of the visualized structure as the cortical layer of bone tissue has optical density (from dense to very porous) and internally it is a rough trabecular bone tissue. D3 bone different type is characterized by a thinner porous cortical bone tissue and thin trabecular bone. In D4 density, there is practically no cortical bone tissue and almost the entire volume of bone is a thin trabecular bone tissue. Very soft bone with incomplete mineralization is classified as D5. It usually corresponds to immature bone [15]. Analysis of the findings on the study of the optical density of the bone enabled to establish that the main pool of patients with MRONJ had the structure of bone tissue architectonics corresponding to types 3 and 4 according to the Misch classification. The bones were almost devoid of a compact layer; the spongy substance was a thin layer of trabecular bone tissue. The optical density of the structures under study ranged from $229.8 \pm 56.6$ to $534.8 \pm 155.4 \mathrm{HU}$. Thus, the quantitative indicators of the jaw bone tissue and classified by types revealed can be regarded as an objective prognostic criterion for assessing the likelihood of developing MRONJ.

\section{CONCLUSION}

Thus, patients with bone types D3, D4, D5 receiving osteomodifying agents are more at risk of developing MRONJ than patients with bone types D1 and D2. We consider it expedient to include the mandatory MSCT with the determination of the optical density of bone tissue and the stratification of bone type according to Misch in the examination protocols of this group of patients. Dispensary observation should be implemented.

The study was conducted within the framework of the state assignment of the Institute for Immunology, Ural Branch of the Russian Academy of Sciences (R\&D registration number AAAA-A18-118020590108-7).

\section{REFERENCES}

1. Shevtsova V.V. Oslozhneniia i pobochnye effekty lecheniia bisfosfonatami s tochki zreniia dokazatelnoi meditsiny [Evidence-based complications and adverse effects of bisphosphonate treatment]. Okhrana Materinstva i Detstva, 2018, no. 1 (31), pp. 60-63. (in Russian)

2. Shibahara T. Antiresorptive agent-related osteonecrosis of the jaw (ARONJ): A twist of fate in the bone. Tohoku J. Exp. Med., 2019, vol. 247, no. 2, pp. 75-86. DOI: 10.1620/tjem.247.75

3. Zhuravleva M.V., Zhuravlev L.V., Firsova I.V. Sovremennyi vzgliad na problemu bisfosfonatnogo osteonekroza cheliustei (obzornaia statia) [Modern view on the problem of bisphosphonate osteonecrosis of the jaws (review article)]. Zhurnal Nauchnykh Statei. Zdorove i Obrazovanie v XXI Veke, 2018, vol. 20, no. 5, pp. 88-92. (in Russian)

4. Fomichev E.V., Kirpichnikov M.V., Podolskii V.V. Bisfosfonatnyi osteonekroz, oslozhnennyi patologicheskim perelomom nizhnei cheliusti [Bisphosphonate osteonecrosis complicated by a pathological fracture of the mandible]. Volgogradskii NauchnoMeditsinskii Zhurnal, 2018, no. 3 (59), pp. 43-45. (in Russian)

5. Fleisher K., Kontio R., Otto S. eds. Antiresorptive Drug-related Osteonecrosis of the Jaw (ARONJ) - a Guide to Research. AOCMF Publ., 2016, 64 p.

6. Mânea H.C., Urechescu H.C., Balica N.C., Pricop M.O., Baderca F., Poenaru M., Horhat I.D., Jifcu E.M., Cloșca R.M., Sarău C.A. Bisphosphonates-induced osteonecrosis of the jaw - epidemiological, clinical and histopathological aspects. Rom. J. Morphol. Embryol., 2018, vol. 59, no. 3, pp. 825-831.

7. Spevak E.M., Khristoforando D.Iu., Gandylian K.S., Sharipov E.M. Opredelenie gistologicheskoi kartiny kostnoi tkani cheliustei $\mathrm{u}$ bolnykh $\mathrm{s}$ bisfosfonatnym osteonekrozom $\mathrm{s}$ tochki zreniia prognozirovaniia iskhodov zabolevaniia [Determination of the histological picture of the jaw bone tissue in patients with bisphosphonate osteonecrosis in terms of predicting the outcome of the disease]. Meditsinskii Vestnik Severnogo Kavkaza, 2016, vol. 11, no. 3, pp. 429-431. (in Russian) 
8. Muthukrishnan A., Bijai Kumar L., Ramalingam G. Medication-related osteonecrosis of the jaw: a dentist's nightmare. BMJ Case Rep., 2016, vol. 2016, pp. bcr2016214626. DOI: 10.1136/bcr-2016-214626

9. Poxleitner P., Engelhardt M., Schmelzeisen R., Voss P. The prevention of medication-related osteonecrosis of the jaw. Dtsch. Arztebl. Int., 2017, vol. 114, no. 5, pp. 63-69. DOI: 10.3238/arztebl.2017.0063

10.Bujaldón-Rodríguez R., Gómez-Moreno G., Leizaola-Cardesa I.O., Aguilar-Salvatierra A. Resolution of a case of denosumabrelated osteonecrosis of the jaw after tooth extraction American Association of Oral and Maxillofacial Surgeons. European Review for Medical and Pharmacological Sciences, 2019, vol. 23, no. 6, pp. 2314-2317. DOI: 10.26355/eurrev_201903_17370

11.Aghaloo T., Hazboun R., Tetradis S. Pathophysiology of osteonecrosis of the jaws. Oral Maxillofac. Surg. Clin. North Am., 2015, vol. 27 , no. 4, pp. 489-496. DOI: 10.1016/j.coms.2015.06.001

12.Alekseev B.Ia., Garin A.M., Gorbunova V.A., Musaev E.R., Manziuk L.V., Stenina M.B., Semiglazova T.Iu., Semenov N.N., Snegovoi A.V.; Obshcherossiiskii Soiuz Obshchestvennykh Obedinenii, Assotsiatsiia Onkologov Rossii. Klinicheskie rekomendatsii po primeneniiu osteomodifitsiruiushchikh agentov u patsientov s metastazami v kosti zlokachestvennykh opukholei [Clinical recommendations on using osteomodifying agents in patients with bone metastases of malignant tumors]. M., 2014, 6 p. (in Russian)

13.Bermúdez-Bejarano E.B., Serrera-Figallo M.Á., Gutiérrez-Corrales A., Romero-Ruiz M.M., Castillo-de-Oyagüe R., Gutiérrez-Pérez J.L., Machuca-Portillo G., Torres-Lagares D. Analysis of different therapeutic protocols for osteonecrosis of the jaw associated with oral and intravenous bisphosphonates. Med. Oral Patol. Oral Cir. Bucal., 2017, vol. 22, no. 1, pp. e43-e57. DOI: 10.4317/ medoral.21477

14.Zaslavskaia N.A., Drobyshev A.Iu., Volkov A.G. Opyt lecheniia osteonekrozov cheliustei u patsientov, poluchaiushchikh antirezorbtivnuiu terapiiu (bisfosfonaty, «denosumab») [Experience in the treatment of the jaw osteonecroses in patients receiving antiresorptive therapy (bisphosphonates, "Denosumab"]. Cathedra-Kafedra. Stomatologicheskoe Obrazovanie, 2014, no. 47, pp. 32-37. (in Russian)

15.Misch C.E. Dental lmplant Prosthetics. Mosby. 2nd Ed. 2014. 1008 p.

16.Zhukova N.A. Stadirovanie bisfosfonatnogo osteonekroza cheliustei u bolnykh zlokachestvennymi novoobrazovaniiami po dannym multisrezovoi kompiuternoi tomografii [Staging of bisphosphonate osteonecrosis of the jaws in patients with malignant neoplasms according to multislice computed tomography]. Meditsinskaia Vizualizatsiia, 2016, no. 3, pp. 17-27. (in Russian)

17.Sletov A.A., Zhidovinov A.V., Mozheiko R.A., Loktionova M.V., Supianov T.M. Sravnitelnyi analiz effektivnosti vizualnykh metodov diagnostiki u patsientov s osteonekrozami i asepticheskimi osteomielitami cheliustnykh kostei [Comparative analysis of the effectiveness of visual diagnostic methods in patients with osteonecrosis and aseptic osteomyelitis of the jaw bones]. Vestnik Volgogradskogo Gosudarstvennogo Meditsinskogo Universiteta, 2017, no. 1 (61), pp. 78-82. (in Russian)

18.Baba A., Goto T.K., Ojiri H., Takagiwa M., Hiraga C., Okamura M., Hasegawa S., Okuyama Y., Ogino N., Yamauchi H., Kobashi Y., Yamazoe S., Munetomo Y., Nomura T. CT imaging features of antiresorptive agent-related osteonecrosis of the jaw/medicationrelated osteonecrosis of the jaw. Dentomaxillofac. Radiol., 2018, vol. 47, no. 4, pp. 20170323. DOI: 10.1259/dmfr.20170323

19.Schiodt M., Vadhan-Raj S., Chambers M.S., Nicolatou-Galitis O., Politis C., Coropciuc R., Fedele S., Jandial D., Zhang J., Ma H., Saunders D.P. A multicenter case registry study on medication-related osteonecrosis of the jaw in patients with advanced cancer. Support. Care Cancer, 2018, vol. 26, no. 6, pp. 1905-1915. DOI: 10.1007/s00520-017-4003-2

20.Shibahara T. Imaging modalities for drug-related osteonecrosis of the jaw (2), Overview of the position paper on medicationrelated osteonecrosis of the jaw and the current status of the MRONJ in Japan. Jpn. Dent. Sci. Rev., 2019, vol. 55, no. 1, pp. 71-75. DOI: $10.1016 /$ j.jdsr.2018.11.003

Received: 23.03 .2020

\section{Information about the authors:}

1. Natalya G. Vinogradova, M.D., Ph.D., Ural State Medical University, Ekaterinburg, Russian Federation, Central City Clinical Hospital, Ekaterinburg, Russian Federation

2. Liliya V. Solomatina, M.D., Ph.D., Institute of Immunology and Physiology of the Ural Branch of the RAS, Ekaterinburg, Russian Federation

3. Marina P. Kharitonova, M.D., Ph.D.,

Ural State Medical University, Ekaterinburg, Russian Federation,

Central City Clinical Hospital, Ekaterinburg, Russian Federation

4. Konstantin V. L'vov, M.D.,

Central City Clinical Hospital, Ekaterinburg, Russian Federation

5. Dmitry Yu. Borzunov, M.D., Ph.D.,

Ural State Medical University, Ekaterinburg, Russian Federation,

Central City Clinical Hospital, Ekaterinburg, Russian Federation,

Email: borzunov@bk.ru 